because of an increase in the serum cholesterol concentration - particularly in that of the low density lipoprotein fraction. ${ }^{15}$ Most of the evidence suggests that this increase in low density lipoprotein cholesterol concentration is short term, and the cholesterol concentration falls to baseline concentrations or below in the long term. ${ }^{1+16} 17$

Thiazides cause other adverse effects, and a recent observation was that of impotence in men taking thiazides in the Medical Research Council trial. ${ }^{9}$ Perhaps as a result the quality of life in patients taking thiazide diuretics may be inferior to that of patients taking propranolol. ${ }^{18}$ Sodium depletion is rarely a problem in patients taking thiazide diuretics alone but may be a problem in patients, particularly in elderly patients, if given together with amiloride-usually as Moduretic. ${ }^{56}$

A diabetogenic effect of thiazides was suspected soon after their first clinical use. ${ }^{19}$ Worsening of glucose tolerance may occur with long term use of thiazides ${ }^{20}$ and seems to be greater with the longer acting members of the class-for example, clopamide. ${ }^{21}$ Diabetes may also occur in patients taking loop diuretics, but clinical problems are unusual with both groups of diuretics. Gout is, however, a common adverse effect of thiazides and other diuretics; but though half of all patients taking thiazides have hyperuricaemia, less than $2 \%$ of patients suffer from clinical gout. ${ }^{22}$ Rashes are occasionally a problem with thiazide diuretics, but only loop diuretics seem to cause ototoxicity. ${ }^{56}$ Clinical problems may arise when diuretics are given with non-steroidal anti-inflammatory drugs as these drugs blunt the hypotensive effects of thiazides. ${ }^{23}$

This liturgy of side effects may persuade some clinicians to stop prescribing thiazides for patients with hypertension, but there are benefits besides the obvious diuretic or hypotensive effect. Thiazides reduce the urinary excretion of calcium (unlike loop diuretics, which increase it), ${ }^{56}$ and there are suggestions that thiazides reduce the rate of recurrence of urinary calculi. ${ }^{24}$ Nevertheless, further trials are needed. Two recent studies, however, have shown a reduced incidence of hip fracture in elderly patients receiving long term treatment with thiazides. ${ }^{25} 26$

Overall, the risk:benefit ratio for thiazides still favours the drugs. We should aim at using the lowest possible dose, as there is a flat dose response curve. ${ }^{27}$ It should rarely be necessary to use more than $2.5 \mathrm{mg}$ of bendrofluazide a day. We should be alert to the possibility of hypokalaemia and take avoiding action either through the diet or the use of potassium sparing diuretics. Combined preparations of thiazide with potassium rarely help. ${ }^{56}$ Finally, we should remember that in large parts of the developing world thiazide diuretics offer the only cost effective way of treating hypertension.

Professor of Clinical Pharmacology,

M ORME

University of Liverpool,

Liverpool L69 3BX

1 Van Brummelen P, Man In't Veld AJ, Schalekamp MADH. Hemodynamic changes during long term thiazide treatment of essential hypertension in responders and non-responders. Clin Pharmacol Ther 1980;27:328-36.

2 Anderson J, Godfrey BE, Hill DM, Munro-Faure AD, Sheldon J. A comparison of the effects of hydrochlorthiazide and of frusemide in the treatment of hypertensive patients. $Q \mathcal{F}$ Med 1971;40:541-60.

$3 \mathrm{McVeigh} \mathrm{G}$, Galloway D, Johnston D. The case for low dose diuretics in hypertension: comparison of low and conventional doses of cyclopenthiazide. Br Med f 1988;297:95-8.

4 Carlsen JE, Kober L, Torp-Pedersen C, Johansen P. Relation between dose of bendrofluazide, antihypertensive effect, and adverse biochemical effects. BrMed f 1990;300:975-8.

antihypertensive effect, and adverse biochemical ef.
Lant AF. Diuretics. A review. Drugs 1985;29:57-87.

6 Lant AF. Diuretics. A review. Drugs $1985 ; 29: 57-87$.

7 Mulfiple Risk Facior Inervenion Trial Research Group. Baseline rn Multiple Risk Factor Intervention Trial Research Group. Baseline rest electrocardiographic
abnormalities, antihypertensive treatment and mortality in the multiple risk factor intervention trial. Am f Cardiol 1985;55:1-5.

8 Hypertension Detection and Follow-up Program Cooperative Research Group. The effect of antihypertensive drug treatment on mortality in the presence of resting electrocardiographic abnormalities at baseline: the HDFP experience. Circulation 1984;70:996-1003

9 Medical Research Council Working Party. MRC trial of treatment of mild hypertension: principal results. Br Med f 1985;291:97-105.

10 Poole-Wilson PA. Diuretics, hypokalaemia and arrhythmias in hypertensive patients: still an unresolved problem. F Hypertens [Suppl] 1987;5:51-5.

1 Hollifield JW. Electrolyte disarray and cardiovascular disease. Am $\mathcal{f}$ Cardiol 1989;63:21B-6B.

12 Khair GZ, Kochar MS. Mild hypertension, diuretics and cardiac arrhythmias: consensus amid controversy. Am Heart $\mathcal{f}$ 1988;116:216-21.

3 Langford HG. The effect of potassium depletion by thiazides. Arch Intern Med 1988;148:1265-6.

14 Freis ED, Papademetriou V. How dangerous are diuretics? Drugs 1985; 30:469-74.

15 Grimm RH Jr, Leon AS, Hunninghake DB, Lenz K, Hannan P, Blackburn H. Effect of thiazid diuretics on plasma lipids and lipoprotein in mildly hypertensive patients. A double blind diuretics on plasma lipids and lipoprotein in
controlled trial. Ann Intern Med 1981;94:7-11.

16 Ames RP. The effects of antihypertensive drugs on serum lipids and lipoproteins. 1. Diuretics. Drugs 1986;32:260-78.

17 Burris JF, Freis ED. Thiazides do not cause long term increases in serum lipid concentrations. Arch Intern Med 1985;145:2264-5.

18 Williams GH, Croog SH, Levine S, Testa MA, Sudilovsky A. Impact of antihypertensive therapy on quality of life: effect of hydrochlorthiazide. 7 Hypertens [Suppl] 1987;5:29-35.

19 Goldner MG, Zarowitz H, Akgun S. Hyperglycaemia and glycosuria due to thiazide derivatives administered in diabetes mellitus. $N$ Engl f Med 1960;262:403-5.

20 Murphy MB, Lewis PJ, Kohner E, Schumer B, Dollery CT. Glucose intolerance in hypertensive patients treated with diuretics: a fourteen year follow up. Lancet 1982;ii: 1293-5.

21 Hicks $B H$, Ward JD, Jarrett RJ, Keen $\mathrm{H}$, Wise P. A controlled study of clopamide and clorexolone and hydrochlorthiazide in diabetes. Metabolism 1973;22:101-9.

22 Beevers DG, Hamilton M, Harpur JE. The long term treatment of hypertension with thiazide diurs DG, Hamilton M, Harpur JE. The

23 Favre L, Glasson Ph, Riondel A, Vallotion MB. Interaction of diuretics and non-steroidal antiinflammatory drugs in man. Clin Sci 1983;64:407-15.

4 Churchill DN, Taylor DW. Thiazides for patients with recurrent calcium stones: still an open question. F Urol 1985;133:749-51.

25 Roy WA, Giffin MR, Downey W, Melton WJ III. Long term use of thiazide diuretics and risk of hip fracture. Lancet 1989;i:687-90.

26 La Croix AZ, Wienpahl J, White LR, et al. Thiazide diuretic agents and the incidence of hip fracture. N Engl F Med 1990;322:286-90.

27 Cranston WI, Juel-Jensen BE, Semmence AM, Handfield-Jones RPL, Forbes JA, Mutch LMM. Effects of oral diuretics on raised arterial pressure. Lancet 1963;ii:966-70.

\title{
The mental health of Asians in Britain
}

\section{Little disease or underreporting?}

Any general statements on the mental health of British Asians are hard to sustain, given the cultural heterogeneity, range of length of settlement in Britain, and variation in eagerness towards (and success in) assimilating into Western culture. Nevertheless, some 50 papers and several reviews have discussed the mental health of people in Britain whose origins lie in the Indian subcontinent, and these suggest that less mental illness is found among most groups of British Asians than might be expected. ${ }^{1-3}$ The competing explanations are that British Asians genuinely experience less mental illness, that general practitioners are less good at identifying or treating mental illness in their Asian patients, and that Asians are reluctant to present with such illnesses.

There is evidence to support the suggestion that British
Asians have less mental illness than the indigenous population. Despite evidence from small studies to the contrary ${ }^{45}$ Asians seem to consult their general practitioners more frequently than do native Britons, ${ }^{6-9}$ but these high consultation rates do not apply when mental illness alone is considered. ${ }^{9}$ Referrals to one east London child psychiatry service, for example, included remarkably few Bengalis. ${ }^{10}$ Moreover, a considerable body of evidence shows that British Asians have low levels of neurotic traits or psychiatric symptoms. ${ }^{511-15}$

Possibly, however, general practitioners are simply not recognising mental illness in their Asian patients. Such a failure may be part of a wider failure to communicate between British doctors and Asian patients. ${ }^{16}{ }^{17}$ One study discovered that general practitioners find it harder to recognise psychi- 
atric symptoms in patients of Asian origin, possibly because the patients are more likely to present symptoms somatically. ${ }^{18}$ Another found that this failure applied to anxiety but not to depression. ${ }^{19}$

An alternative explanation is that general practitioners recognise signs of mental illness but think it inappropriate to treat or refer patients and leave this to other agencies. Such behaviour may not be confined to general practitioners born and trained in Britain. Those trained in the Indian subcontinent and practising in Britain are less likely than their British counterparts to think it appropriate for patients to consult with family problems and may overtly or tacitly discourage patients with such problems from attending. ${ }^{20}$ Psychiatry has low status within medical education in India, ${ }^{21}$ and one study has shown that general practitioners in India can identify only a quarter of probable cases of psychiatric morbidity. ${ }^{22}$

A widespread view is that much illness, particularly mental illness, remains managed within the Asian family. No attempt has been made to test this idea, although the belief affects action: general practitioners, for example, are inhibited from referring Asian patients to district nursing services. ${ }^{23}$ Nevertheless, some evidence supports the idea. Bengali children referred to a child psychiatry service in east London presented a narrower range of problems than white children. ${ }^{10}$ This may indicate Asian patients' unwillingness to proceed to further treatment, especially that requiring admission to hospital, which is seen as a mark of serious illness. ${ }^{64}{ }^{25}$ Referral to a psychiatrist may affect marriage prospects. ${ }^{26}$

Some patients may be shielded from medical care more than others. Studies of general practitioner consultation rates suggest that contact is particularly inhibited for women, ${ }^{7-9}$ who seem to be uncertain of expectations in a doctor-patient relationship, ${ }^{27}$ especially when the general practitioner is a man. ${ }^{28}$ Many requests to a phone-in advice service for ethnic minorities were from women with severe life crises who were seeking the help of a woman doctor..$^{29}$

An additional reason for low presentation rates for mental illness is that ideas of psychological causation of illness are poorly understood within Asian cultures. ${ }^{2430} 31$ Moreover, treatment by general practitioners for conditions such as depression and anxiety has become commonplace only in the last generation, and it is hardly surprising if older Asians behave differently in seeking help for such conditions. ${ }^{32}$ Patients may sidestep conventional medical services and prefer to approach hakims or other alternative healers, but there is little evidence that this happens on a major scale. ${ }^{233} 34$ Mentally ill British Asians may, however, travel to Asia for treatment: almost a quarter of those from one sample who had visited the subcontinent had visited an Asian healer while they were there. ${ }^{33}$

Although British Asians may thus show both genuinely low rates of mental illness and a tendency to underreport mental illness, their prevalence of mental illness will probably gradually reach national levels, both overall and for particular diagnoses. In the meantime Asian patients may need encouragement to express their emotional problems in psychological terms and doctors need to develop a greater sensitivity in recognising them.

Senior Research Fellow,

Newham Health Authority,

London E13 0DZ

1 London M. Mental illness among ethnic minorities in the UK. Br f Psychiatry 1986;149:265-73. 2 Ineichen B. The mental health of Asians in Britain: a research note. New Community 1987;14: 136-41.

3 Leff J. Psychiatry around the globe: a transcultural view. 2nd ed. London: Gaskell/Royal College of Psychiatrists, 1988.

4 Brewin C. Explaining the lower rates of psychiatric treatment among Asian immigrants to the United Kingdom: a preliminary study. Soc Psychiatry 1980;15:17-9.
Mahmud S. Life stress and symptoms: a comparative study of Pakistani and English women. In: Dent H, ed. Clinical psychology: research and development. London: Croom Helm, 1987:111-7. Blakemore K. Ethnicity, self-reported illness and use of medical services by the elderly. Postgrad Med f 1983;59:668-70.

Murray J, Williams P. Self-reported illness and general practice consultations in Asian born and British born residents of West London. Soc Psychiatry 1986;21:139-45.

Gillam SJ, Jarman B, White P, Law R. Ethnic differences in consultation rates in urban general practice. BrMed f 1989;299:958-60.

Balarajan R, Yuen P, Raleigh V. Ethnic differences in general practice consultations. Br Med $\mathcal{F}$ 1989;299:958-60.

10 Stern G, Cottrell D, Holmes J. Patterns of attendance of child psychiatry out-patients with special reference to Asian families. Br I Psychiatry 1990;156:384-7.

11 Hill D. Personality factors among adolescents in ethnic minority groups. Educational Studies 1975;1:43-54.

12 Karlarackal AM, Herbert M. The happiness of Indian immigrant children. New Society $1976 \mathrm{Feb}$ 26:422-4

3 Cochrane R, Stopes-Roe M. Psychological and social adjustment of Asian immigrants in Britain: a community survey. Soc Psychiatry 1977;12:195-206.

14 Cochrane R, Stopes-Roe M. Psychological symptom levels in Indian immigrants to England: a comparison with native English. Psychol Med 1981;11:319-27.

15 Cochrane R. Social creation of mental illness. London: Longman, 1983.

16 Ebden P, Carey OJ, Harrison B, Bhatt A. The bilingual consultation. Lancet 1988;i:347:

7 Stevens KA, Fletcher RF. Communicating with Asian patients. Br Med f 1989;299:905-6.

$8 \mathrm{Bal} \mathrm{SS}$. Psychological symptomatology and health beliefs of Asian patients. In: Dent $\mathrm{H}$, ed. Clinical psychology: research and development. London: Croom Helm, 1987:101-10.

19 Nayani $S$. The evaluation of psychiatric illness in Asian patients by the hospital anxiety depression scale. Br f Psychiatry 1989;155:545-7.

20 Cartwright A, Anderson R. General practice revisited. London: Tavistock, 1981.

21 Cohen D. Forgotten millions. London: Paladin, 1988.

21 Cohen D. Forgotten millions. London: Paladin, 1988.

Shamasundar C, Murthy SK, Prakash OM, Prabhakar N, Krishna DKS. Psychiatric morbidity in general practice. BrMed f 1986;292:1713-5.

23 Badger F, Atkin K, Griffiths R. Why don't general practitioners refer their disabled Asian patients to district nurses? Health Trends 1989;21:31-2.

24 Henley A. Asian patients in hospital and at home. London: King's Fund, 1979.

25 Rack P. Race, culture and mental disorder. London: Tavistock, 1982.

6 Qureshi B. Transcultural medicine: dealing with patients from different cultures. Dordrecht: Kluwer, 1988.

27 Donovan J. Black people's health: a different approach. In: Rathwell T, Phillips D, eds. Health, race and ethnicity. London: Croom Helm, 1986:137-74.

28 Currer C. Pathan mothers in Bradford. Coventry: University of Warwick, 1983.

29 Webb P. Health problems of London's Asians and Afro-Caribbeans. Health Visitor 1981:54:141-7.

Skultans V. Psychiatric community care: a Marastrian example. Psychol Med 1986;16:499-501. mental disorder among Indian patients: preliminary report of work in progress. Soc Sci Med mental disorder

32 Manning M. Transcultural psychiatry. Community Care 1979;248:19-21.

33 Bhopal RS. The inter-relationship of folk, traditional and Western medicine within an Asian community in Britain. Soc Sci Med 1986;22:99-105.

34 Johnson MRD. Inner city residents, ethnic minorities and primary health care in the West Midlands. In: Rathwell T, Phillips D, eds. Health, race and ethnicity. London: Croom Helm, 1986;192-212.

\section{Atherosclerotic renovascular disease}

\section{Remediable cause of renal failure in the elderly}

Renovascular disease has long been recognised as a cause of hypertension and renal impairment, ${ }^{12}$ but the syndrome consists of two quite different conditions with few common features.

A young woman with renal artery stenosis as the cause of her hypertension will most commonly have an artery that has been narrowed by medial hyperplasia. The less commonly recognised variant is the older patient with widespread vascular disease and hypertension in whom the renal artery or arteries have been narrowed by atherosclerotic disease. Atherosclerotic renal artery stenosis has a high likelihood of progression to occlusion and a $40 \%$ probability of development of contralateral stenosis within four years. ${ }^{34}$ In contrast to medial hyperplasia, therefore, atherosclerotic renovascular disease often presents when a significant stenosis has developed in a solitary kidney, the other kidney having previously and silently lost function owing to renal artery occlusion. ${ }^{5}$

Recent studies have confirmed the high prevalence of atherosclerotic renal artery stenosis in the elderly population. In one study 39 of 106 patients presenting with hypertension and renal impairment and in another $14 \%$ of patients over the age of 50 presenting with advanced renal failure had renal artery disease as the underlying cause.$^{56}$ Furthermore, half of the patients with advanced renal failure were being treated with an angiotensin converting enzyme inhibitor when renal failure developed. The action of this group of drugs in precipitating acute renal failure in patients with bilateral 